\title{
ELEK IMRE
}

\section{Házi készítésü lőszerek töltényhüvelyeinek nyomszakértői vizsgálata, a lőszertöltő gép egyedi azonosításának lehetőségei}

\begin{abstract}
A Bünügyi Szakértői és Kutatóintézet nyomszakértőjeként számos szakértői kirendelés kapcsán foglalkozom eszköznyomok és nyomképző eszközök vizsgálatával. A nyomképző eszközök, a nyomhordozók, valamint a nyomképződési mechanizmusok végtelen variációs lehetősége miatt szinte lehetetlen felsorolni, hányféle elkövetési eszköz és nyomhordozó objektum kerülhet egymással olyan fizikai kapcsolatba, amely értelmezhető traszológiai nyomok kialakulásához vezet.

Egy olyan esetről számolok be, ahol az említett fizikai kapcsolat egy kisipari felhasználású lőszertöltő gép és a lőszeralkatrészek között jött létre. A lőszertöltési mechanizmus során a töltényhüvelyen létrejövő traszológiai elváltozások, amelyek a nyomképződés statikus vagy akár a dinamikus fázisában keletkeznek, elegendő egyedi sajátosságokkal szolgálhatnak. A konkrét ügyben a lőszertöltő gép sérült alkatrésze miatt statikus nyomsajátosságok adtak lehetőséget az egyedi azonosításra. A szakértői feladat teljesítésekor egy újabb vizsgálati módszert is teszteltünk annak érdekében, hogy kiderüljön: az észlelhetőség határán leképeződött dinamikus nyomsajátosságok milyen minőségben detektálhatók. A vizsgálatok, teszteredmények rávilágítottak arra, hogy e nyomsajátosságok talán még nagyobb esélyt adhatnak a hasonló ügyek jövőbeni szakértői bizonyításában.

A téma aktualitását az adja, hogy hazánkban - valószínűleg költségmegtakarítási okból - terjedőben van a házilag történő lőszertöltés, és várható, hogy a jövőben egyre több esetben kerül sor hasonló vizsgálatokra.
\end{abstract}

\section{Az ügy elözményei}

A 2014. évben a nyugati országrészben orvvadászat miatt állampolgári bejelentés érkezett a területi rendőri szervhez. A bejelentés után több személynél tartottak házkutatást, amelynek keretében orvvadászathoz használható, engedély nélkül tartott lőfegyvert, lőszereket és lőszeralkatrészeket foglaltak le. A 
nyomozás során a gyanúsítotti kör bővülésével egy löszertöltő berendezés is előkerült, amellyel az orvvadászathoz használt löszereket készíthették. A nyomozás során szakértői kirendelésre került sor, amely két kompetenciaterületet érintett. Az ügyhöz kapcsolódó bủnjelek esetében összehangolt fegyverszakértői és nyomszakértői vizsgálatra került sor. A kilőtt lőszerhüvelyeknél és fegyvereknél fegyvermúködési nyomok vizsgálatát, míg a kilőtt lőszerhüvelyek, lőszerek és a lőszertöltő berendezés viszonylatában a gyártógép nyomának összehasonlító vizsgálatát végeztük el.

\section{A bünjelek vizsgálata}

Az átadott lőszerek és kilőtt töltényhüvelyek vizsgálatát megelőzően tanulmányoztam a lőszertöltő gép müködési mechanizmusát, és feltérképeztem a traszológiailag releváns nyomképzö felületeket. A vizsgált készülék egy viszonylag egyszerü mechanikus szerkezet, amelynek töltényhüvely és lövedék befogására, feltámasztására alkalmas szerkezeti elemei vannak, és e lőszeralkatrészek egymásba illesztésére, sajtolására alkalmas karos emelöje. A berendezés müködési mechanizmusának vizsgálatakor megállapítottam, hogy a löszertöltés különböző fázisaiban a töltényhüvely több része is érintkezik a berendezés szerkezeti elemeivel. Vizsgáltam, hogy melyek azok a fizikai kölcsönhatások, amelyek hatására a vizsgálatra alkalmas nyom kialakul, valamint hogy a nyomképződési mechanizmusokat milyen módon lehet modellezni. A lőszertöltő gép müködési mechanizmusának megismerése után egyértelmű volt, hogy nyomképzőként a berendezés hüvelyprés alkatrésze vehető számításba, mivel ez az alkatrész volt az, amely a töltényhüvely nyakrészével érintkezett és a nyom keletkezése szempontjából elegendő nyomképző erőt mutatott. Ez az alkatrész a töltő fázisban dinamikus, a töltési végállapotban statikus nyomot hagy. A lőszertöltő gép befogószerszámába a töltényhüvely tetszőleges rotációs pozícióban rögzíthető, ezért a nyomképzödési pálya a müködés alapján csak részben határozható meg.

Ennek az alkatrésznek a nyomképző felületeit vizsgálva arra a megállapításra jutottam, hogy egyedi nyomképződés szempontjából a természetes használat következtében kialakuló mechanikai jellegü elváltozások (például sérülés, deformálódás és az alkatrész gyári megmunkálása) nyomán kialakult a felszíni mikrostruktúra, például a hüvelyperem szegélyének mikroszkopikus egyenetlensége. 
A kérdéses töltényhüvelyek geometriai paramétereivel megegyező töltényhüvelyekre a lőszertöltő géppel próbanyomokat telepítettünk. A nyomokat az összehasonlító vizsgálat előtt megvizsgáltuk egyrészt azért, hogy a feltételezett nyomképződési mechanizmusoknak van-e optikailag detektálható eredményük, másrészt azért, hogy a próbanyomok bármelyikén keletkezett-e valamilyen észlelhető elváltozás. A vizsgálatokhoz Leica M650 szteromikroszkópot és az intézetben közelmúltban rendszerbe állított Evofinder 3D szkenner ballisztikai azonosító rendszer optikai letapogatóját használtuk. A sztereomikroszkópon felkutatott statikus nyomsajátosságokat, amelyek a nyomképződés statikus végállapotában keletkeztek, Leica M400 fotomakroszkópra illesztett Leica MC120 HD digitális kamerával is rögzítettük. A nyomképződés dinamikus fázisában létrejövő dinamikus nyomokat az Evofinder 3D szkenner képfeldolgozó szoftverével örökítettük meg.

Szakértői szempontból meglepő volt, hogy a töltényhüvely nyakrészén, a teljes palást felszínén jól leképeződött dinamikus nyomstruktúrának kis részletét sem lehetett a WILD M400 fotomakroszkóppal elégséges szinten dokumentálni. Az Evofinder által készített palástfelvétel ezzel ellentétben minden részletében tartalmazott olyan barázdákból és barázdaárkokból álló egyedi sajátosságokat, amelyek a további összehasonlító vizsgálatra alkalmasak (1. számú ábra).

Az általunk vizsgált lőszertöltő berendezés hüvelyprésének alkatészén olyan mechanikai jellegü sérülések voltak, amelyeknek az alakja a próbanyomokban következetesen leképeződött. Ezek a sérülések csekély méretük ellenére geometriai szabálytalanságuk folytán elegendő egyedi jelleggel bírtak, és a próbanyom három darabból álló sorozatának minden tagjában változatlan alakjellegzetességgel képeződtek le. A lőszertöltő gép egyedi azonosítha-

1. számú ábra

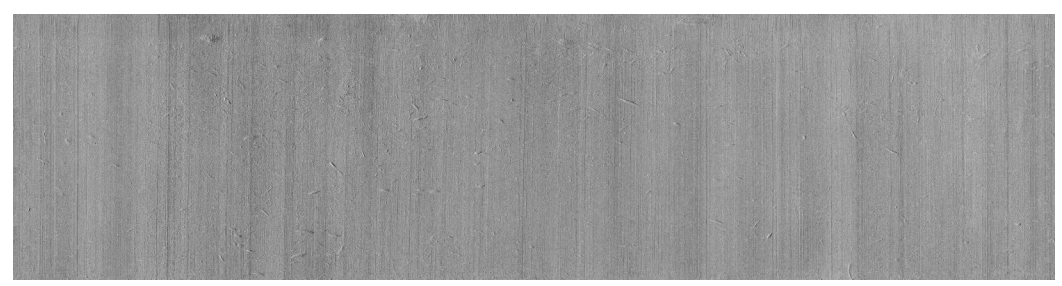

A kép egy töltényhüvely nyakrészének 26,37 milliméteres kiterített palástját ábrázolja. A palást felszínén láthatók a töltényhüvely hossztengelyével azonos irányú dinamikus eszköznyomok, amelyek a lőszertöltő berendezéstől származnak, és a töltési végállapot előtti dinamikus fázisban keletkeztek. Az ábrázolt nyom minden részletében hordoz egyedi sajátosságot. Forrás: Bünügyi Szakértői és Kutatóintézet. Készítette: Kiss István igazságügyi fegyverszakértő. Képrögzítés eszköze: Evofinder optikai 3D szkenner ballisztikai azonosító rendszer. 
tóságára a statikus eszköznyom önmagában is elegendő volt, így a szakvélemény kategorikus vizsgálati eredményét ennek a nyomnak az egyedi azonosítása alkotta (2. számú ábra).

Megvizsgáltuk, hogy a gyári kialakítású alkatrészek, különösen a hüvelyprés milyen állandósággal képesek reprodukálni az azonosításra alkalmas nyomsajátosságokat, ha a lőszertöltő gép nyomképző alkatrészei sérülésmen-

2. számú ábra
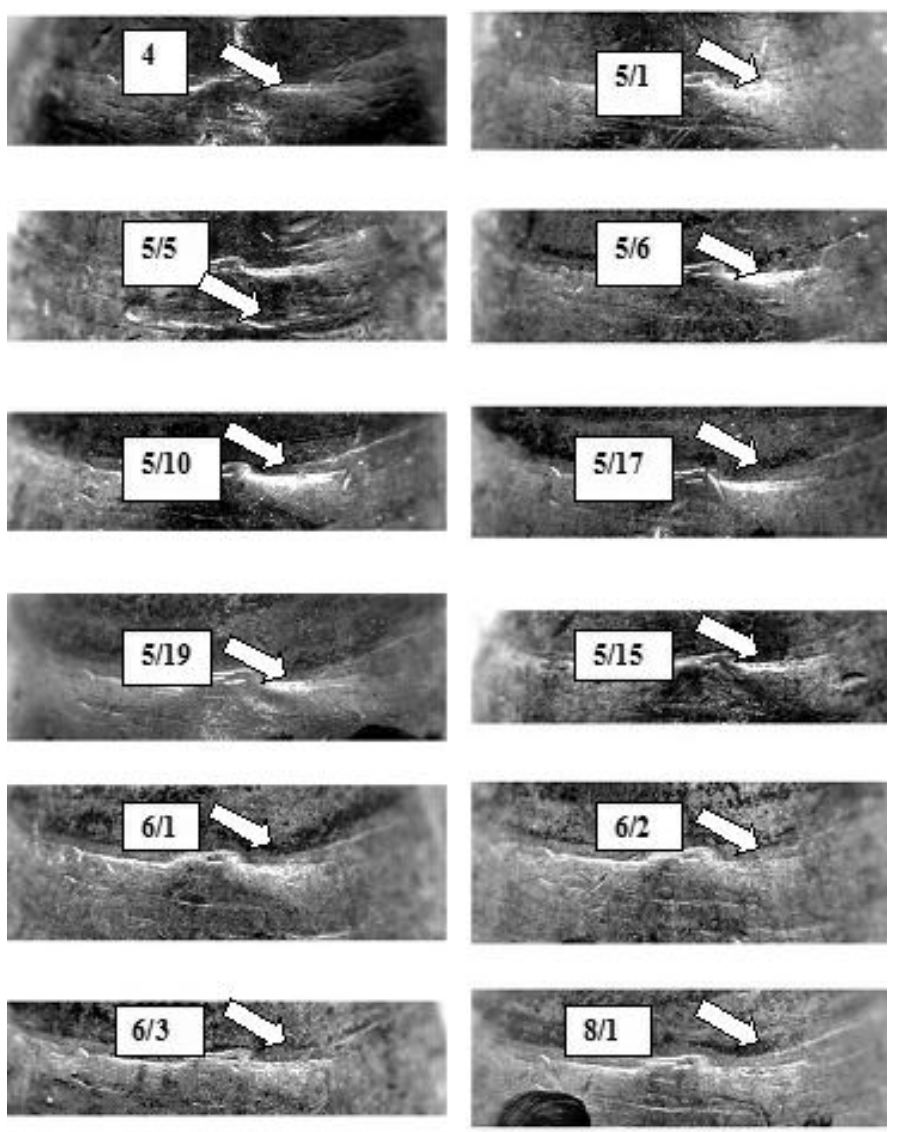

A képsorozat a különböző sorszámokkal jelölt töltényhüvelyek nyakrészeinek részleteit ábrázolja. Az azonos beállítású felvételeken a lőszertöltő gép hüvelyprésének statikus nyomrészletei jól mutatják a nyomhagyó eszköz érintkező határfelületének mechanikai sérülését, amely a töltési végállapot statikus fázisában keletkezett. Az ábrázolt nyom szabálytalan felszíne egyedi jelleget hordoz. Forrás: Bünügyi Szakértői és Kutatóintézet. Készítette: Komolai György nyomszakértőjelölt. Képrögzítés eszköze: WILD M400 fotomakroszkóp. 
tesek, valamint a természetes elhasználódás miatt nem alakult ki rajtuk egyéb felületi elváltozás. Annak kiderítésére, hogy a jövőben jelentősége lehet-e ennek a problémakörnek a szakértői bizonyításoknál, ugyanezeket a nyomhordozókat és kérdéses töltényhüvelyeket tovább vizsgáltuk. Az Evofinder optikai letapogatójával rögzített képeket összehasonlítottuk. A teljes dinamikus nyomstruktúrán belül olyan nyomrészletet kerestünk, amely profilogramjában a legösszetettebb. Később az összes nyom esetében ezt a nyomrészletet kerestük. Az egyezőnek vélt nyomrészleteket pozicionáltuk, mivel a kiterített palástfelvételeken a sajátossági pontok eltérő helyre kerültek, majd ez után dokumentáltuk (3. számú ábra).

3. számú ábra

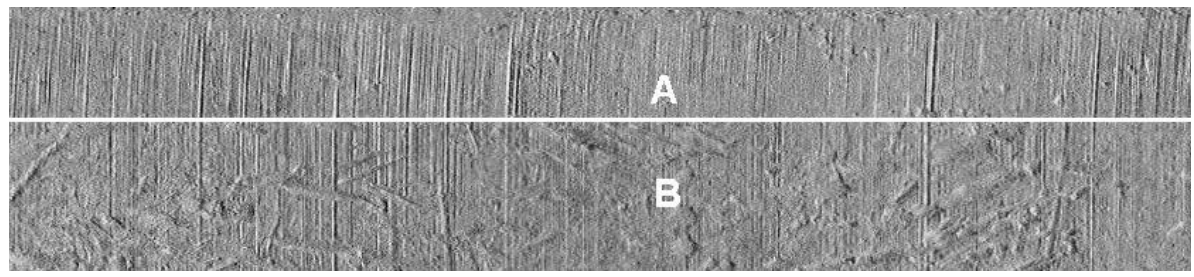

A kép két töltényhüvely nyakrészének kiterített palást részletét ábrázolja. Az $A$ jelü nyom a gyanúsítottól lefoglalt töltényhüvelyen, a $B$ jelü próbanyom. A palástok közötti illesztési határt a fehér vízszintes vonal jelzi. A palástok felszínén láthatók a töltényhüvely hossztengelyével azonos irányú dinamikus eszköznyomok, amelyek mindkét palástrészen egybeesnek. Forrás: Bűnügyi Bünügyi Szakértői és Kutatóintézet. Készítette: Kiss István igazságügyi fegyverszakértő. Képrögzítés eszköze: Evofinder optikai 3D szkenner ballisztikai azonosító rendszer.

\section{Összegzés}

Vizsgálataink végén az adott ügyben pozitív azonosítást végeztünk, amelynek alapjául a lőszertöltő gép egyik alkatrészének apró sérülése szolgált. A vizsgálatieredmény-közlés kategorikus állásfoglalást tartalmazott abban a kérdésben, hogy a két gyanúsítottól lefoglalt töltények és az ellőtt töltényhüvelyek egy harmadik gyanúsítottól lefoglalt lőszertöltő gép nyomait hordozták. Az adott ügyben történt szakkérdések megválaszolásán túl a vizsgálatsorozat szakértői szempontból is adott új információt, mivel az Evofinder 3D optikai szkenner segítségével egy olyan dinamikus nyomképződést sikerült dokumentálni, amire korábban nem volt lehetőség. 


\section{IRODALOM}

Katona Géza: A nyomok azonosítási vizsgálata a büntetőeljárásban. Közgazdasági és Jogi Könyvkiadó, Budapest, 1965

Illár Sándor: Bevezetés a krimináltechnikába. BM Kiadó, Budapest, 1984, 5-26. o.

Tremmel Flórián - Fenyvesi Csaba: Kriminalisztika Tankönyv és Atlasz. Dialóg Campus Kiadó, Budapest-Pécs, 2002

Bócz Endre (szerk.): Kriminalisztika. BM Kiadó, Budapest, 2004, 1160. o.

Lakatos János: Kriminalisztikai alapismeretek. Rendőrtiszti Főiskola, Budapest, 2005, 172. o. Fenyvesi Csaba - Herke Csongor - Tremmel Flórián: Kriminalisztika - Tankönyv és Atlasz. Dialóg Campus Kiadó, Budapest-Pécs, 2005

Tremmel Flórián: Bizonyítékok a büntetőeljárásban. Dialóg Kiadó, Budapest-Pécs, 2006, 58. o.

Tóth Éva - Belovics Ervin: A büntetőeljárás segédtudományai I. kötet. PPKE JÁK, Budapest, 2015, 607. o.

Finszter Géza: A kriminalisztika elmélete és a praxis a büntetőeljárási reform tükrében. http://be.atw.hu/letoltes/Krimjegyzet.doc 